\title{
Assessment of the levels of polychlorinated biphenyls (PCBs) in Orogodo River sediments Agbor, Delta State, Nigeria
}

\author{
Oghenekohwiroro EDJERE ${ }^{1, *}$ and Osaro IYEKOWA ${ }^{2}$ \\ ${ }^{1}$ Department of Environmental Management and Toxicology, Federal University of Petroleum Resources, \\ Effurun, Delta State, Nigeria \\ ${ }^{2}$ Department of Chemistry, University of Benin, Benin City, Nigeria
}

\begin{abstract}
The study aimed at assessing the levels of polychlorinated biphenyls (PCBs) concentration in Orogodo River Sediments at Agbor, Delta State, Nigeria. Sixteen sediment samples at different sample point were collected and analyzed; obtained concentrations were compared with exiting standards. Sediment samples were extracted using a mixture of hexane and acetone (1:1), sonicated in an ultrasonic bath $(15 \mathrm{~min})$ and placed on a shaker for two hours. Chromatographic analysis was done after solvent exchange, was carried out on the final extract using $n$-hexane $(1000 \mu \mathrm{l})$ and injected $(1 \mu \mathrm{l})$ into a gas chromatographic system coupled with an electron capture detector (ECD). Results from this study revealed that the concentration of PCBs in all the sediment samples under investigation was highest with $0.198 \mu \mathrm{g} / \mathrm{kg}$ in the Agric yard Agbor 2 sample point and lowest with $0.026 \mu \mathrm{g} / \mathrm{kg}$ in the Behind Prison - Agbor 1. The concentration of PCBs for all the sediment samples analyzed ranged in the order: Agric Yard Agbor $2<$ Slaugther Agbor $2<$ River Ama $1<$ Mr. Biggs Agbor $1<$ Behind Prison Agbor $2<$ River Ama 2 < Mr. Biggs Agbor $3<$ Under Bridge Agbor $1<$ Mr. Biggs Agbor $2<$ River Ama $4<$ Agric Yard Agbor $1<$ Mr. Biggs Agbor $4<$ SlaugtherAgbor $1<$ River Ama $3<$ Under Bridge Agbor $2<$ Behind Prison Agbor 1. The obtained results in this study suggest the urgent need to establish a program for monitoring organochlorine pollutants in our rivers and sediment in other to curb any elevation in concentration of pollutants over the environmental quality standards and appropriate actions taken.
\end{abstract}

Keywords: Polychlorinated biphenyls, sediment, extraction, chromatography.

\section{Introduction}

Polychlorinated biphenyls (PCBs) constitute a large class of compounds produced by the partial or complete chlorination of the biphenyl molecule. These organic oils enter the environment through poor handling of damaged electrical equipment, leakages, spillage during retro filling and illegal dumping of PCB containing waste in the seas and environment and could have severe implication on the food web which may have deleterious effect on important soil nutrient necessary for plant growth [1]. However, contaminated PCBs soil particles might be transported by storm water runoff into lakes and rivers. Once the PCBs reach a lake or a river, they concentrate in the sediment of the lake. Crustaceans, snails, and other organisms that live in the sediment ingest these organic materials [2]. Fish that consume these organisms might also be contaminated with PCBs. PCBs tend to accumulate with each successive step in the food chain. They adhere to the surfaces of organic particles in the water column, resulting in their eventual deposition and accumulation in sediments.
Research report from different authors reveals serious health effects from exposure to PCBs. Ward et al. [3] reported that PCBs are likely causes of cancer and are classified as a "probable carcinogen" by the federal Environmental Protection Agency (FEPA, Nigeria) and the International Agency for Research on Cancer. They further reported studies that found children's risk of developing acute lymphocytic leukemia, increased by two-fold when PCBs were detected in the dust of a room in which the child spent a significant amount of time. Weisglas-Kuperus [4] reported the effect of PCBs in immune system of organisms; Schell [5] stated the effects of PCBs on thyroid function. It causes an elevated risk of cardiovascular disease [6], hypertension and diabetes [7]. They can alter the sex hormone systems, and have been found to lower the age at which a girl reaches puberty [8] and can reduce the levels of the male hormone, testosterone [9]. They cause an overall increased risk of asthma and other infectious respiratory disease [10]. More specifically, children have an increased risk of asthma and other infectious respiratory diseases when exposed to persistent organic pollutants, including PCBs [11].

"Corresponding author. E-mail address: edjere.oghenekohwiroro@ fupre.edu.ng Tel: +2347088102415

(Oghenekohwiroro EDJERE) 
Women who are exposed to PCBs have babies that weigh slightly less than babies from women who have not been exposed, this was reported by the Federal Agency for Toxic Substances \& Disease Registry. In addition, children born to women who ate PCBcontaminated foods have abnormal responses in tests of infant behavior, including problems with motor skills and a decrease in short-term memory, reduction in learning ability and cognitive problems have been associated with PCBs [12]. This study owes it significance to the fact that sediment serves as both a source and a removal mechanism for contaminants to and from the stream, and as a means of contaminant transport downstream. Sediment also provides habitat for benthic biota, and can be ingested by them. Accumulation of contaminants can cause harm to the biota and to those who consume them. More also, aquatic biotas are important in the food web around the stream, and some organisms such as fish are consumed by people and birds. Since stream bed sediment can adsorb higher concentrations of organic compounds than the surrounding water, therefore, analysis of sediment increases the likelihood of detecting compounds that are present in the stream. Hence, the aim of this study is to determine the levels of the concentration of PCBs in sediments samples from Orogodo River and also comparing the concentration with established standards.

\section{Materials and methods}

\subsection{Study area}

Orogodo River lies within the humid tropical zone with defined dry season (November - March) and rainy season (April - October). The rainy season is brought about by the South-West Trade Wind blowing across the Atlantic Ocean, while the dry, dusty, and often cold North-East Trade Wind blowing across the Sahara desert dominates the dry season with a short spell of harmattan. The relative humidity of the area is high and increases from $70 \%$ in January to $80 \%$ in July. The average atmospheric temperature of the area is about $25.5{ }^{\circ} \mathrm{C}$ in the rainy season and about $30{ }^{\circ} \mathrm{C}$ in the dry season. Orogodo River is located between latitudes $5^{\circ} 43^{\prime} \mathrm{N}$ and $5^{\circ} 30^{\prime} \mathrm{N}$ and longitudes $6^{\circ} 20^{\prime} \mathrm{E}$ and $6^{\circ} 12^{\prime} \mathrm{E}$, and takes its source from Mbiri village at an elevation of $150 \mathrm{~m}$ above sea level. The river serves as a major source of water for drinking, bathing, fishing, washing, and recreation for the people of Agbor and Owa communities in Delta State, Nigeria. The Agbor and Owa communities, through which the Orogodo River transverses, are mainly peasant farmers whose products include food stuff such as yams, corn, vegetables, cassava, plantain and fruits. Agricultural activities in the area are mostly carried out along the bank of the Orogodo River, and agricultural wastes (domestic wastes, livestock manure, fertilizers and pesticides) are discharged directly into the river or entrained in runoff into the river after rainfall.

\subsection{Soil sample collection}

A total of sixteen soil samples approx. (200 g each) at a depth of $0-15 \mathrm{~cm}$ and minimum of $50 \mathrm{~m}$ apart were collected from site using a stainless steel shovel along the river and close to different (electronic waste, car wash, abattoirs, domestic waste etc.) dumpsites. Samples were packed with aluminum foil into clean polyethylene bags and transported to the laboratory. Soils were air dried at ambient temperature for a month and subsequently ground to powder form using a laboratory mortar and pestle, then passed through a $2 \mathrm{~mm}$ sieve.

\subsection{Extraction}

Extraction of polychlorinated biphenyls (PCBs) and their purification was done using a modified procedure described by [13]. After each soil sample has been homogenized, $10 \mathrm{~g}$ were weighed into a 500 $\mathrm{ml}$ Duran glass container with a seal. Two surrogates PCB Nr. 209 and tetrachloronaphthalene (TCN) were then added as required. About $10 \mathrm{~g}$ of sodium sulfate (drying agent) was added to absorb moisture contents present in the sample. $50 \mathrm{ml}$ of the solvent mixture of $n$-hexane and acetone $(1: 1)$ used for extraction were added to the solution. Thereafter, the mixture was agitated in an ultrasonic bath for 20 minutes, in order to further enhance proper interaction; the mixture was transferred to rotator shaker where extraction lasted for two hours. The extract was allowed to settle for one hour, an aliquot of the extract was taken and added to $1 \mathrm{ml}$ ISTD-solution $(2.5 \mu \mathrm{l} 1,11$ dibromundecane in $250 \mathrm{ml}$ hexane) before being concentrated to $1 \mathrm{ml}$ [14].

\subsection{Clean up}

Clean up was carried out on the soil sample extracts using silica based SPE cartridges. A combined double effect of $1 \mathrm{~g}$ (cartridge) ISOLUTE SAX/SCX (Biotage, Sweden) was used as follows: pre-conditioning of the cartridges was performed using approximately $4 \mathrm{ml}$ of the eluting solvent (hexane) under very low vacuum condition (35 millibar or $0.51 \mathrm{psi})$. The complete extract concentrated to $1 \mathrm{ml}$ was introduced directly into the isolute cartridge and extract was allowed to stand for 5 minutes before eluting with approximately $5 \mathrm{ml}$ of hexane. The collected elute was then concentrated with nitrogen to $1 \mathrm{ml}$ ready for gas chromatographic injection.

\subsection{Blank}

Procedure described by [13] and [14] were adopted for preparation of blank samples.

\subsection{Chromatographic analysis}

The sample extract dissolved in $1 \mathrm{ml}$ hexane was injected $(1 \mu \mathrm{l})$ into a gas chromatographic system at $280{ }^{\circ} \mathrm{C}$ (GC6000, Vega Series 2, Carlo Erba Instruments) with an electron capture detector attached (ECD 80/800, Fisons Instruments), operating at a temperature of $320^{\circ} \mathrm{C}$. The sample was carried by helium gas, the make-up gas was nitrogen. 
The GC system was fitted with a fused silica capillary column compose of $5 \%$ phenyl-substituted dimethylpolysiloxane phase of dimension $0.25 \mathrm{~mm}$ i.d. $\times 60 \mathrm{~m}, 0.25 \mu \mathrm{m}$ film thickness (CP-Sil 8 CB Low Bleed/MS, Varian (1) or HP-5, Hewlett Packard (2). The oven temperature program was held isothermally at $90^{\circ} \mathrm{C}$ for $1 \mathrm{~min}$, then programmed at $40^{\circ} \mathrm{C} \cdot \mathrm{min}^{-1}$ to $210{ }^{\circ} \mathrm{C}$, held for $0.5 \mathrm{~min}$, again programmed at 5.6 ${ }^{\circ} \mathrm{C} \cdot \mathrm{min}^{-1}(1)$ or $2.6{ }^{\circ} \mathrm{C}(2)$ to $230{ }^{\circ} \mathrm{C}$, held for $10 \mathrm{~min}$, next increased by $5.6^{\circ} \mathrm{C} \cdot \mathrm{min}^{-1}$ (1) or $2.6^{\circ} \mathrm{C}$ (2) to 275 ${ }^{\circ} \mathrm{C}$ and held for $20 \mathrm{~min}$. The identification and determination of PCB concentration peaks was based on retention time comparisons and the individual peak areas in the sample chromatogram with peak retention times and areas of standards respectively.

\subsection{Quality Control}

As a routine measure, spiking using surrogate recovery in each sample was used to get information on losses of analyte from the extraction step through to analysis. However, no single PCB can be a representative of all of the PCBs being determined, and thus recovery correction was performed with caution.

Blank correction was carried out for all samples using a robust method based on a blank known to be representative of a batch of samples.

Bachema AG Laboratory Switzerland, where the analysis was carried out used an internally validated version of EPA 8082, with method LOQ (limit of quantification) of $0.002 \mathrm{mg} / \mathrm{kg}$, with a method error margin of $\pm 0.0004 \mathrm{mg} / \mathrm{kg}(12-24 \%)$. The values are means of two runs after extraction of samples using a GC-ECD [15].

The methodology adopted in this study for PCBs in sediment by Bachema AG (Quality Management Guidelines, Bachema QRL-Verzeichnis, MethodenSAW 351-06 - PCB in Festoffen 34/68) is in line with EPA 8082 [15].

\section{Results and discussion}

The results of the assessment of the trace level of $\mathrm{PCBs}$ in $\mathrm{mg} / \mathrm{kg}$ present in Orogodo River sediments at Agbor is shown in Table 1.

Table 1. Concentration of PCBs in $\mathrm{mg} / \mathrm{kg}$ of sediment present in Orogodo River, Agbor, Delta State.

\begin{tabular}{|c|c|c|c|c|c|c|c|c|}
\hline Sample location & $\begin{array}{c}\text { PCB } \\
28 \\
\end{array}$ & $\begin{array}{c}\text { PCB } \\
52\end{array}$ & $\begin{array}{c}\text { PCB } \\
101 \\
\end{array}$ & $\begin{array}{l}\text { PCB } \\
118\end{array}$ & $\begin{array}{l}\text { PCB } \\
138\end{array}$ & $\begin{array}{l}\text { PCB } \\
153\end{array}$ & $\begin{array}{l}\text { PCB } \\
180\end{array}$ & $\begin{array}{l}\text { PCB } \\
(\mathrm{SUM}) * 4.3\end{array}$ \\
\hline Mr. Biggs Agbor 1 & 0.002 & 0.004 & 0.005 & 0.003 & 0.003 & 0.002 & 0.003 & 0.082 \\
\hline Mr. Biggs Agbor 2 & 0.001 & 0.003 & 0.005 & 0.003 & 0.002 & $<0.001$ & 0.002 & 0.056 \\
\hline Mr. Biggs Agbor 3 & 0.002 & 0.004 & 0.005 & 0.002 & 0.001 & $<0.001$ & 0.003 & 0.065 \\
\hline Mr. Biggs Agbor 4 & 0.002 & 0.003 & 0.004 & 0.001 & 0.001 & $<0.001$ & $<0.001$ & 0.043 \\
\hline Agric Yard Agbor 1 & 0.002 & 0.003 & 0.005 & 0.002 & 0.002 & $<0.001$ & $<0.001$ & 0.052 \\
\hline Agric Yard Agbor 2 & 0.001 & 0.003 & 0.04 & 0.002 & 0.002 & $<0.001$ & $<0.001$ & 0.198 \\
\hline Under Bridge Agbor 1 & 0.002 & 0.003 & 0.007 & 0.003 & 0.002 & $<0.001$ & $<0.001$ & 0.060 \\
\hline Under Bridge Agbor 2 & 0.001 & 0.003 & 0.003 & $<0.001$ & $<0.001$ & $<0.001$ & $<0.001$ & 0.030 \\
\hline SlaugtherAgbor 1 & 0.002 & 0.002 & 0.005 & 0.001 & $<0.001$ & $<0.001$ & 0.001 & 0.043 \\
\hline SlaugtherAgbor 2 & 0.004 & 0.014 & 0.008 & 0.002 & $<0.001$ & $<0.001$ & 0.001 & 0.116 \\
\hline Behind Prison Agbor 1 & $<0.001$ & 0.001 & 0.005 & $<0.001$ & $<0.001$ & $<0.001$ & $<0.001$ & 0.026 \\
\hline Behind Prison Agbor 2 & 0.003 & 0.006 & 0.008 & $<0.001$ & $<0.001$ & 0.001 & 0.001 & 0.082 \\
\hline River Ama 1 & 0.003 & 0.011 & 0.008 & 0.002 & $<0.001$ & 0.001 & 0.001 & 0.103 \\
\hline River Ama 2 & 0.002 & 0.002 & 0.011 & 0.003 & 0.002 & $<0.001$ & $<0.002$ & 0.073 \\
\hline River Ama 3 & $<0.001$ & 0.001 & 0.007 & 0.002 & $<0.001$ & $<0.001$ & $<0.001$ & 0.034 \\
\hline River Ama 4 & 0.001 & 0.002 & 0.008 & 0.002 & $<0.001$ & $<0.001$ & 0.001 & 0.052 \\
\hline
\end{tabular}




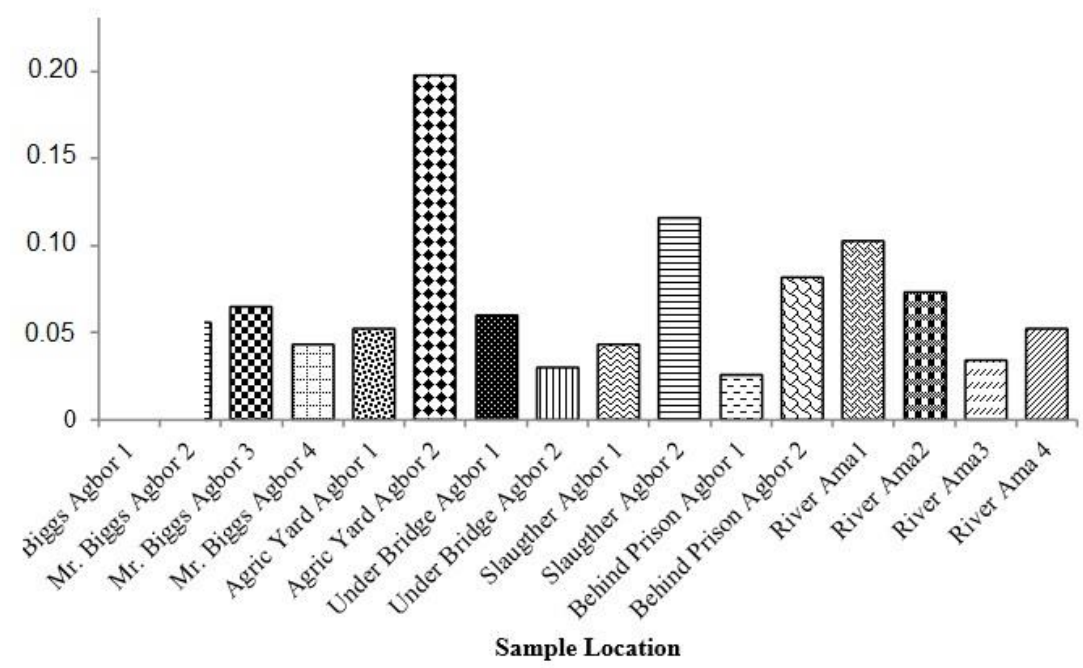

Figure 1. Total concentration of PCBs in $\mathrm{mg} / \mathrm{kg}$ for sediment in Orogodo River, Agbor, Delta State

PCBs were determined in sixteen different sediment locations along Orogodo River, Agbor, Delta State. The concentration of PCB in sediment matrix was considerably low. Though, samples were collected from different sample locations with varying degrees of contamination, the results of this study is in line with the general knowledge of the fate of PCBs in the environment and food chain [16]. Trace level of PCBs concentrations in marine sediment has been the greatest threat for their determination. Reports from relevant literature reveals that lower concentrations of the analyte, may lead to inaccurate results. According to literature on QUASIMEME (Quality Assurance of Information for Marine Environmental Monitoring in Europe) laboratory performance studies report with analyte concentrations $<1 \mathrm{mg} / \mathrm{kg}$, may yield false analytical results for PCBs [17, 18]. Despite the enormous challenges in comparing laboratory performances and getting results from adopting good quality control measures, inter laboratory comparisons are useful for guiding researchers in developing their methods. In this study, concentration of PCBs in sediment sample was highest with $0.198 \mathrm{mg} / \mathrm{kg}$ in the Agric Yard Agbor 2 sample point and lowest with $0.026 \mathrm{mg} / \mathrm{kg}$ in the Behind Prison - Agbor 1. PCBs concentrations were high in sample site such as Agric Yard Agbor 2, Slaugther Agbor 2, River Ama 1, Behind Prison Agbor 2 and Mr. Biggs Agbor 1 with concentration of $0.198 \mathrm{mg} / \mathrm{kg}, 0.116 \mathrm{mg} / \mathrm{kg}, 0.103 \mathrm{mg} / \mathrm{kg}, 0.082$ $\mathrm{mg} / \mathrm{kg}$ and $0.082 \mathrm{mg} / \mathrm{kg}$ respectively. While the concentration of PCBs were lowest in sediment sample of River Ama 2, Mr. Biggs Agbor 3, Under Bridge Agbor 1, Mr Biggs Agbor 2, Agric Yard Agbor 1, River Ama 4, Mr. Biggs Agbor 4, Slaugther Agbor 1, River Ama 3, Under Bridge Agbor 2 and Behind Prison Agbor 1 with values of $0.073 \mathrm{mg} / \mathrm{kg}$, $0.065 \mathrm{mg} / \mathrm{kg}, 0.060 \mathrm{mg} / \mathrm{kg}, 0.056 \mathrm{mg} / \mathrm{kg}, 0.052$ $\mathrm{mg} / \mathrm{kg}, 0.056 \mathrm{mg} / \mathrm{kg}, 0.056 \mathrm{mg} / \mathrm{kg}, 0.043 \mathrm{mg} / \mathrm{kg}$, $0.034 \mathrm{mg} / \mathrm{kg}, 0.030 \mathrm{mg} / \mathrm{kg}$ and $0.026 \mathrm{mg} / \mathrm{kg}$. The concentration of PCBs for all the sediment samples analyzed ranged in the order: Agric Yard Agbor $2<$ Slaugther Agbor $2<$ River Ama $1<$ Mr. Biggs Agbor $1<$ Behind Prison Agbor $2<$ River Ama $2<\mathrm{Mr}$. Biggs Agbor $3<$ Under Bridge Agbor $1<$ Mr. Biggs Agbor $2<$ River Ama $4<$ Agric Yard Agbor $1<$ Mr. Biggs Agbor 4 < SlaugtherAgbor $1<$ River Ama $3<$ Under Bridge Agbor $2<$ Behind Prison Agbor 1 . Although PCBs concentration obtained in sediment samples from various sampling site were within tolerant limit. It has been reported by [16] that PCBs bioaccumulate, and has good solubility in fats of living things [16]. This can be dangerous, when stored in aquatic lives, as there is tendency of moving up the food chain (transferring to man) as its final host. Hence, strict measures should be adopted to eliminate its presence from the environment.

\section{Conclusions}

This study had been able to established correlation between the concentrations of PCBs in the Orogodo River when compared with the available standards. While PCBs concentrations of sediment samples in this study were within tolerance limit, the highest PCBs concentration was recorded by the Agric Yard Agbor 2 sample locations. The obtained results in this study, points to the urgent need to establish a program for monitoring organochlorine pollutants in our rivers, so that any elevation in concentration of pollutants over the environmental quality benchmark can be detected and appropriate actions taken.

\section{Conflict of interests}

The authors declare that there is no conflict of interests. 


\section{References}

[1]. R.F. Noss (2008). "Endangered Species." Microsoft ${ }^{\circledR}$ Encarta ${ }^{\circledR} 2009$ [DVD]. Redmond, WA: Microsoft Corporation

[2]. J.K. Bentum, D.K. Dodoo, P.K. Kwakye, Accumulation of metals and polychlorinated biphenyls (PCBs) in soils electric transformers in the central region of Ghana, Adv. Appl. Sci. Res. 3 (2012) $634-643$

[3]. M.H. Ward, J.S. Colt, C. Metayer, Residential exposure to polychlorinated biphenyls and organochlorine pesticides and risk of childhood leukemia, Environ. Health Perspect. 117 (2009) 1007-13. DOI: 10.1289/ehp.0900583

[4]. N. Weisglas-Kuperus, H.J. Vreugdenhil, P.G. Mulder, Immunological effects of environmental exposure to polychlorinated biphenyls and dioxins in Dutch school children, Toxicol. Lett. 149 (2004) 281-285. DOI: 10.1016/j.toxlet.2003.12.039

[5]. L.M. Schell, M.V. Gallo, M. Denham, J. Ravenscroft, A.P. DeCaprio, D.O. Carpenter, Relationship of thyroid hormone levels to levels of polychlorinated biphenyls, lead, $p, p^{\prime}$-DDE, and other toxicants in Akwesasne Mohawk youth, Environ Health Perspect. 116 (2008) 806-813.

[6]. A. Goncharov, R.F. Haase, A. Santiago-Rivera, G. Morse, R.J. McCaffrey, R. Rej, D.O. Carpenter, High serum PCBs are associated with elevation of serum lipids and cardiovascular disease in a native American population, Environ. Res. 106 (2008) 226-39. DOI:10.1016/j.envres.2007.10.006

[7]. D.H. Lee, M.W. Steffes, A. Sjödin, R.S. Jones, L.L. Needham, D.R. Jacobs Jr., Low dose of some persistent organic pollutants predicts type 2 diabetes: a nested case-control study, Environ Health Perspect. 118 (2010) 1235-1242. DOI:10.1289/ehp.0901480

[8]. M. Denham, L.M. Schell, G. Deane, M.V. Gallow, J. Ravenscroft, A.P. DeCaprio, Relationship of lead, mercury, mirex, dichlorodiphenyldichloroethylene, hexachloro-benzene, and polychlorinated biphenyls to timing of menarche among Akwesasne Mohawk girls, Pediatrics $115 \quad$ (2005) 127-134. DOI: 10.1542/peds.2004-1161

[9]. A. Goncharov, R. Rej, S. Negoita, A. SantiagoRivera, G. Morse, Akwesasne Task Force on the
Environment, D.O. Carpenter, Lower serum testosterone associated with elevated polychlorinated biphenyl concentrations in native American men, Environ. Health Perspect. 117 (2009) 1454-1460.

DOI: $10.1289 /$ ehp.0800134

[10].D.O. Carpenter, J. Ma, L. Lessner, Asthma and infectious respiratory disease in relation to residence near hazardous waste sites, Ann. N. Y. Acad. Sci. 1140 (2008) 201-208.

[11]. J. Ma, M. Kouznetsova, L. Lessner, D.O. Carpenter, Asthma and infectious respiratory disease in children - correlation to residence near hazardous waste sites, Paediatr. Respir. Rev. 8 (2007) 292-298.

[12]. S.L. Schantz, J.J. Widholm, D.C. Rice, Effects of PCB exposure on neuropsychological function in children, Environ. Health Perspect. 111 (2003) 357-376.

[13]. A. Filipkowska, Determining PCBs in fish and sediment samples related to intercomparison studies, Pol. J. Environ. Stud. 22 (2013) 13411347.

[14]. O. Osibanjo, A. Adeyeye, Organochlorine pesticide residues in cereals in Nigerian markets, Bull. Environ. Contam. Toxicology 54 (1995) 460-465. DOI: 10.1007/BF00195121

[15]. Bachema AG Laboratories (2017). Dienstleistungsverzeichnis. DLV17_19_17, p. 34. Retrieved from www.bachema.ch

[16]. H. Skarphedinsdottir, K. Gunnarsson, G.A. Gudmundsson, E. Nfon, Bioaccumulation and biomagnification of organochlorines in a marine food web at a pristine site in Iceland, Arch. Environ. Con. Tox. 58 (2010) 800-809. DOI: 10.1007/s00244-009-9376-x

[17]. J. De Boer, D.E. Wells, Chlorobiphenyls and organochlorine pesticides in fish and sediments - three years of QUASIMEME Laboratory Performance Studies, Mar. Pollut. Bull. 35 (1997) 52-63. DOI: 10.1016/S0025326X(97)00123-9

[18].A. Filipkowska, Determining PCBs in fish and sediment samples related to intercomparison studies, Pol. J. Environ. Stud. 22 (2013) 1341 1347.

Received: 13.03 .2017

Received in revised form: 27.06.2017

Accepted: 30.06.2017 